\title{
Handwashing promotion and the use of hand sanitizer as a preventative measure on the development of bacteria
}

\author{
Irma Suswati ${ }^{\mathrm{a}, 1^{*}}$, Anisa Putri Maulida ${ }^{\mathrm{a}, 2}$ \\ ${ }^{a, b}$ Medical Education, Medical Faculty, Universitas Muhammadiyah Malang, East Java, Indonesia \\ ${ }^{1}$ dr_irma_s@yahoo.co.id; ${ }^{2}$ nisabong@gmail.com \\ * Corresponding author
}

\section{ARTICLE INFO}

\section{Article history}

Received: 14 March 2020

Revised: 20 March 2020

Accepted: 17 April 2020

Published: 30 April 2020

\section{Keywords}

Bacteria

Hand sanitizer

Hand washing promotion

Preventative measure

\begin{abstract}
A proper handwashing practice in Indonesia is around $49,8 \%$. A report from Basic Health Research 2018 recorded that Indonesians did not practice proper handwashing. This article aims to determine level of knowledge, number, and type of bacteria on hands. This community service program was conducted to 20 participants of the Regional Office of 'Aisyiyah Malang through handwashing promotion using cleaners (such as soap, wet tissue, and hand sanitizer) to be applied to media called Nutrients Agar Plate (NAP). Then, the participants were to do gram staining to count number, type, and morphology of bacteria. The method implemented was desciptive data analysis. Finding shows that in the aspect of knowledge level, $75 \%$ of the participants were able to answer all questions correctly after the handwashing promotion program. On the count, there were 154 colonies of bacteria growing on unwashed fingers; 8 colonies on the fingers using hand sanitizer; 36 colonies on the fingers washed with soap, and 29 colonies with wet tissue. Handwashing habits provides knowledge to individuals of healthy living behaviour to prevent bacterial growth. It is concluded that hands washed with soap and running water, hand sanitizer, and wet tissue can actually reduce number of bacterial colonies as they contain bactericidal or bacteriostatic chemicals. Types of bacteria from coccus and Gram-positive rods are Staphylococcus, Streptococcus or Corynebacterium.
\end{abstract}

Copyright (C) 2020, Suswati et al This is an open access article under the CC-BY-SA license

\section{Check for updates}

How to cite: Suswati, I., Maulida, A.P. (2020). Handwashing promotion and the use of hand sanitizer as a preventative measure on the development of bacteria . Journal of Community Service and Empowerment, 1(1), 31-36. doi: https://doi.org/10.22219/jcse.v1i1.11510

\section{PENDAHULUAN}

Perilaku hidup bersih dan sehat (PHBS) merupakan upaya promotif dan preventif untuk meningkatkan derajat kesehatan bangsa dan masyarakat. Tiga pilar pembangunan bidang kesehatan salah satunya adalah perilaku hidup sehat dengan cara mencuci tangan dengan sabun. Cuci tangan dianggap sebagai hal yang sepele di masyarakat (Perrys, 2015), cuci tangan merupakan salah satu tehnik dasar yang paling penting untuk pencegahan dan pengontrolan infeksi. Penelitian Burton tahun 2011 membuktikan cuci tangan pakai sabun lebih efektif dibanding cuci tangan menggunakan air, sabun dapat memindahkan kuman. Pengetahuan masyarakat tentang cuci tangan pakai sabun tinggi namun praktik di lapangan masih rendah. Laporan Riskesda 2018 menunjukkan bahwa perilaku benar dalam cuci tangan pada penduduk dengan usia > 10 tahun di Indonesia didapatkan rerata 49,8\% yang melakukan kebiasaan cuci tangan dengan benar (Burton, 2011).

Tangan merupakan bagian tubuh yang mudah tercemar bibit penyakit, dengan mencuci tangan dapat menghilangkan sejumlah besar virus, bakteri, parasit maupun jamur yang menjadi penyebab berbagai penyakit (Kemenkes, 2014). Menurut Departemen kesehatan Indonesia, 2009 cuci tangan pakai sabun dapat mencegah beberapa penyakit seperti (1) infeksi saluran pernapasan, dengan cuci tangan kuman pernapasan yang terdapat di tangan dan permukaan telapak tangan dapat dihilangkan. (2) Diare yang ditularkan melalui jalur fecal-oral yang masuk kedalam mulut melalui jari-jari tangan, mencuci tangan pakai sabun dapat mencegah penularan kuman penyakit, (3) Infeksi cacing, mata dan penyakit 
kulit. Hasil penelitian membuktikan penggunaan sabun saat cuci tangan mengurangi kejadian penyakit kulit, infeksi mata seperti trakoma dan cacingan khususnya ascariasis dan trichuriasis (Permenkes, 2017). Hasil studi WHO, 2007 membuktikan bahwa angka kejadian diare dapat menurun sebesar $45 \%$ dengan perilaku cuci tangan pakai sabun, selain itu data WHO juga memperlihatkan bahwa cuci tangan dengan sabun mampu menurunkan kasus Infeksi Saluran Pernafasan Atas (ISPA) dan flu burung hingga 50\% (Mustikawati, 2017).

Laporan Riset Kesehatan Dasar (Riskesdas) 2018 perilaku cuci tangan yang benar, jika penduduk melakukan cuci tangan dengan menggunakan sabun dan air mengalir sebelum menyiapkan makanan, setiap kali tangan kotor (memegang uang, binatang dan berkebun), setelah buang air besar, setelah mencebok bayi/anak, setelah menggunakan pestisida/insektisida, sebelum menyusui bayi dan sebelum makan. Pada laporan tersebut menunjukkan bahwa perilaku benar dalam cuci tangan dipengaruhi oleh pendidikan, yang tamat D1 atau sarjana didapatkan 64,1\% melakukan kebiasaan mencuci tangan dengan benar, sedangkan pendidikan yang tidak sekolah hanya 39,4\% yang melakukan kebiasaan cuci tangan dengan benar. Berdasarkan kelompok usia yang paling rendah (43\%) memiliki kebiasaan cuci tangan dengan benar pada kelompok usia 10-14 tahun, sedangkan kelompok usia yang paling banyak (54\%) memiliki kebiasaan cuci tangan dengan benar pada usia 45-49 tahun. Berdasarkan tempat tinggal kebiasaan cuci tangan yang benar di perkotaan sebesar 55,5\% dan diperdesaan sebesar 42,7\%. Dari laporan Riskesdas 2018 menunjukkan bahwa penduduk Indonesia masih kurang untuk melakukan kebiasaan cuci tangan sebagai salah satu perilaku hidup sehat (Riskesdas, 2018).

Cuci tangan pakai sabun yang dipraktikkan secara tepat dan benar merupakan cara termudah dan efektif untuk mencegah penyakit, menghilangkan kotoran dan debu secara mekanis dari permukaan kulit dan secara bermakna mengurangi jumlah mikroorganisme. Seiring kesibukan masyarakat terutama perkotaan, maka muncul produk inovasi pembersih tangan tanpa air yang berisi antiseptik seperti hand sanitizer. Hand sanitizer sangat efektif mengurangi insidensi penyakit gangguan pencernaan dan dapat menjaga kebersihan tangan dan mengurangi penularan penyakit didalam rumah tangga. Selain hand sanitizer pembersih tangan yang juga sering dipakai oleh masyarakat adalah tisu basah dan tisu kering. Hasil penelitian menggunakan gel hand sanitizer dengan bahan aktif alkohol 60\% dan tisu basah antiseptik dengan bahan aktif benzalkonium klorida 0,1\% efektif dalam mengurangi jumlah koloni kuman di tangan (Wahyuni, 2017). Bahan aktif yang digunakan yang digunakan untuk sabun cuci tangan adalah triclocarban, benzalkonium chloride, alcohol, biodegradable surfactants, emollient, triclosan dan bahan aktif lainnya (Rolf, 2014).

Kulit manusia mengandung nutrisi yang dipergunakan untuk pertumbuhan mikroorganisme dari hasil proses keratinisasi, jumlah kuman dipengaruhi oleh banyaknya nutrisi tempat tumbuh bakteri (Benny E, 2010). Tubuh manusia secara terus menerus terpapar berbagai mikroorganisme, di kulit seperti Escherichia coli, Salmonella sp, Shigella sp, Clostridium perfringens, Giardia lamblia, virus Norwalk dan virus hepatitis A, jika terjadi perubahan keseimbangan dan daya tahan tubuh mengalami penurunan flora transien dapat berubah menjadi patogen dan menimbulkan penyakit (Jawet, 2017). Kegiatan pengabdian penting dilakukan untuk mencegah dan dapat menurunkan angka kematian pada 5.000 balita penderita diare yang morbiditasnya meningkat akibat kutangnya akses pada air bersih, fasilitas sanitasi dan pendidikan kesehatan yang mudah seperti cuci tangan (Kemenkes, 2014).

Berdasarkan pada hasil penelitian terdahulu; Burton (2011), Mustikawati (2017), Riskesdas (2018), Wahyuni (2017), Rolf (2014), Benny E. (2010), dan Jawet (2017) belum pernah ada penerapan langsung terkait penyuluhan dan praktik yang diarahkan untuk mengetahui tingkat pengetahuan, jumlah dan jenis bakteri di tangan kepada masyarakat secara langsung. Pengabdian masyarakat ini sangat urgen dilaksanakan sebagai tindakan preventif untuk meningkatkan derajad kesehatan masyarakat dan bangsa dengan perilaku hidup sehat.

Mencuci tangan dengan sabun adalah salah satu tindakan sanitasi dengan membersihkan tangan dan jari jemari menggunakan air dan sabun pada tubuh manusia untuk memutuuskan rantai kuman (Kemenkes, 2014). Mengingat masih kurangnya perilaku hidup sehat dengan melakukan cuci tangan pada kelompok usia balita dan diatas >50 tahun (Brilian, 2016), serta resiko timbulnya penyakit dan terjadi penularan penyakit melalui tangan, maka perlu dilakukan kegiatan pengabdian dengan memberikan penyuluhan tentang cuci tangan menggunakan tujuh langkah cuci tangan serta mengetahui jumlah dan jenis bakteri dengan berbagai pembersih tangan (Kemenkes, 2014). Tujuan artikel ini untuk mengetahui tingkat pengetahuan setelah diberi penyuluhan tentang cuci tangan dan mengetahui jumlah dan jenis bakteri pada tangan yang tidak dibersihkan dengan tangan yang menggunakan pembersih tangan berupa sabun, tisu basah, tisu kering dan hand sanitizer. Hasilnya dapat digunakan sebagai aktivitas keseharian untuk melakukan tindakan pencegahan terhadap infeksi dengan melakukan cuci tangan, yang merupakan salah satu dari PHBS.

\section{METODE}

Kegiatan pengabdian masyarakat ini dilakukan di Kantor Pimpinan Daerah 'Aisyiyah (PDA) Kota Malang. Waktu pengabdian dilakukan pada Bulan Januari 2019. Sampel dilakukan bersama anggota PDA sebanyak 20 orang yang hadir di kantor PDA. Kegiatan pengabdian ini melibatkan mahasiswa Fakultas Kedokteran Universitas Muhammadiyah Malang semester 2. Kegiatan berupa penyuluhan, kuesioner pre-test dan post-test tentang tujuh langkah cuci tangan dan menempelkan jari tangan yang diberi pembersih tangan di media Nutrien Agar Plate (NAP). Bahan uji berupa sabun, tisu basah, tisu kering dan hand sanitizer. Media menggunakan NAP. Alat menggunakan autoklaf, incubator, colony counter, pewarnaan Gram (Kristal violet, Lugol, Alkohol, Safranin). 
Cara mengukur tingkat pengetahuan partisipan: sebelum penyuluhan partisipan diminta mengisi pre-test, kemudian diberi penyuluhan tentang tujuh langkah cuci tangan sesuai dengan urutan dan diminta post-test, setelah itu partisipan mendemonstrasikan tujuh langkah cuci tangan dengan benar menggunakan sabun. Partisipan dibagi menjadi 5 kelompok untuk menempelkan jari telunjuk pada NAP. Kelompok 1, 4 jari telunjuk dari partisipan yang tidak dibersihkan diletakkan pada NAP no. 1; kelompok 2, 4 jari telunjuk dari partisipan yang mencuci tangan dengan sabun dan air mengalir diletakkan pada NAP no. 2; kelompok 3, 4 jari telunjuk partisipan yang bersihkan dengan tisu basah diletakkan pada NAP no. 3; kelompok 4, jari telunjuk dari 4 partisipan yang dibersihkan dengan tisu kering diletakkan pada NAP no. 4, dan kelompok 5 jari telunjuk dari 4 partisipan yang dibersihkan dengan hand sanitizer diletakkan pada NAP no. 5. Setelah selesai 5 NAP tersebut dimasukkan dalam incubator dengan suhu $37^{\circ} \mathrm{C}$ selama 24 jam kemudian di hitung jumlah koloni kuman dengan colony counter secara manual dan spesimen koloni tersebut diambil untuk dilakukan pengecatan dengan pewarnaan Gram. Pewarnaan Gram dilakukan dengan beberapa pewarnaan menggunakan cairan kristal violet, lugol, alkohol 96\%, dan safranin, dan dilihat dibawah mikroskop dengan pembesaran 1000x kemudian lihat hasil pewarnaan, morfologi kuman (bentuk batang atau coccus), dan bentuk kuman. Analisis data secara deskriptif.

\section{HASIL DAN DISKUSI}

Kegiatan penyuluhan diberikan pada partisipan anggota PDA berupa tujuh langkah cuci tangan yang benar. (1) Basahi kedua telapak tangan setinggi pertengahan lengan memakai air yang mengalir, ambil sabun kemudian usap dan gosok kedua telapak tangan secara lembut. (2) Usap dan gosok juga kedua punggung tangan secara bergantian (3) Jangan lupa jari-jari tangan, gosok sela-sela jari hingga bersih, (4) Bersihkan ujung jari secara bergantian dengan mengatupkan, (5) Gosok dan putar kedua ibu jari secara bergantian, (6) Letakkan ujung jari ke telapak tangan kemudian gosok perlahan, (7) Bersihkan kedua pergelangan tangan secara bergantian dengan cara memutar, kemudian diakhiri dengan membilas seluruh bagian tangan dengan air bersih yang mengalir lalu keringkan memakai handuk atau tisu. Sebelum penyuluhan dilakukan pre-test dan setelah penyuluhan diberi post-test dengan soal yang sama, hasil kuesioner pada Tabel 1.

Table 1. Hasil pre-test dan post-test tentang pengetahuan tujuh langkah cuci tangan

\begin{tabular}{ccccc}
\hline \multirow{2}{*}{ Jawaban Soal Benar } & & Hasil Pre-test dan post-test pengetahuan 7 langkah cuci tangan \\
\cline { 2 - 5 } & Pre-test & Persentase & Post-test & 1 \\
\hline 0 & 2 & 10 & 60 & 4 \\
1 & 12 & 30 & 15 & 20 \\
\hline Total & 6 & 100 & 75 \\
\hline
\end{tabular}

Tabel 1 menunjukkan bahwa sebagian besar 75\% partisipan pengabdian tingkat pengetahuannya meningkat dan mampu menjawab semua soal dengan benar, walaupun sebagian kecil 25\% belum menjawab semua benar. Artinya penyuluhan yang diberikan telah dimengerti oleh partisipan, namun belum mengukur perilaku sehat mencuci tangan dengan benar.

Jumlah koloni dan jenis bakteri yang tumbuh di Media NAP. Jari telunjuk sampel sesuai dengan tugas kelompok ada yang tidak diberi pembersih tangan dan ada yang dibersihkan dengan tisu basah, tisu kering dan hand sanitizer ditempelkan pada media NAP dan dimasukkan dalam incubator. Jenis koloni yang tumbuh pada media NAP, koloni bentuk bulat, warna putih, tepi regular, tidak berbau dengan ukuran yang berbeda-beda. Hasil perhitungan jumlah koloni pada tabel 2

\begin{tabular}{|c|c|c|c|c|c|}
\hline Jenis Pembersih & 1 & II & III & IV & Rerata \\
\hline Tidak cuci tangan & 265 & 28 & 295 & 26 & 154 \\
\hline Cuci tangan dengan sabun & 30 & 32 & 78 & 4 & 36 \\
\hline Tisu kering & 147 & 49 & 313 & 62 & 143 \\
\hline Tisu basah & 13 & 9 & 64 & 29 & 29 \\
\hline Hand sanitier & 7 & 7 & 14 & 4 & 8 \\
\hline
\end{tabular}

a. I, II, III, IV merupakan pengulangan pemeriksaan sampel

Jumlah koloni yang tumbuh pada media NAP sebagian besar rerata 154 koloni bakteri tumbuh pada partisipan yang tidak cuci tangan dan yang jari tangan di basuh dengan tisu kering rerata 143, sedangkan koloni yang tumbuh sebagian kecil rerata 8 koloni pada jari tangan dengan pembersih hand sanitizer, menggunkan sabun rerata 36 koloni dan tisu basah 29 koloni. Koloni yang tumbuh dilakukan pengecatan dengan menggunakan pewarnaan Gram, hasil seperti pada gambar 1. 


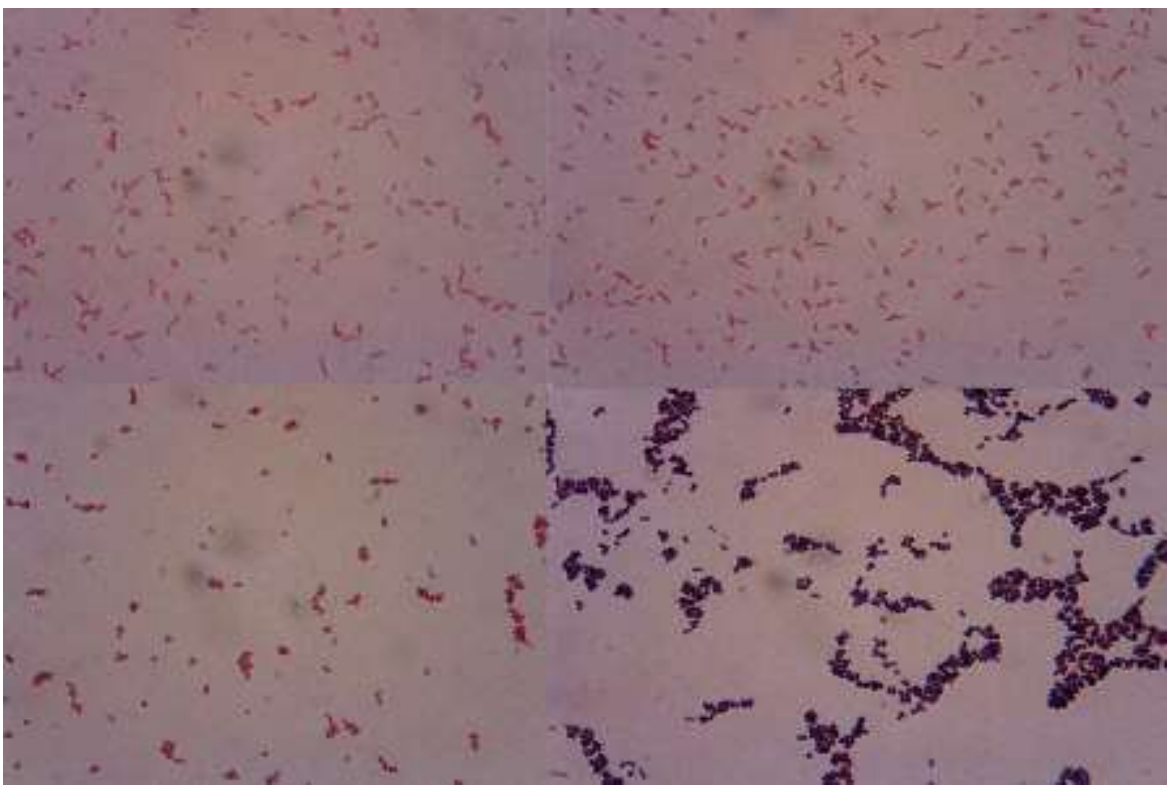

Gambar 1. Hasil pewarnaan gram, bentuk coccus gram positif berwarna ungu

Koloni yang tumbuh dan dilakukan pewarnaan Gram pada beberapa koloni yang berbeda didapatkan hasil sebagian besar bentuk coccus dengan pewarnaan Gram positif berwarna ungu, pada media NAP dengan menggunakan hand sanitizer pada koloni yang berbeda ditemukan morfologi berbentuk batang dengan pewarnaan Gram positif berwarna ungu.

Hasil tingkat pengetahuan partisipan setelah diberi penyuluhan mampu menjawab soal dengan benar $75 \%$, hal ini menunjukkan bahwa untuk menerapkan perilaku sehat perlu diberikan penyuluhan untuk mengingat kembali tentang pentingnya hidup sehat. Pengetahuan dipengaruhi oleh beberapa hal seperti pendidikan formal maupun non formal, pendidikan formal menurut laporan Riset Kesehatan Dasar 2018, proporsi perilaku benar dalam cuci tangan prosentase berdasarkan pendidikan yang tidak sekolah, tidak tamat SD lebih rendah (39,4-43,8\%) dibanding pendidikan yang lebih tinggi tamat D1/D2/D3/PT (64,1\%). Pendidikan formal memberikan kontribusi pengetahuan yang besar tentang perilaku cuci tangan, hal ini kemungkinan pendidikan mempengaruhi pengetahuan. Pengetahuan bisa didapatkan melalui pendidikan non formal yang disampaikan oleh tenaga kesehatan atau pemerhati kesehatan dengan cara penyuluhan tentang cuci tangan. Selain itu, pengetahuan non formal bisa melalui media seperti televisi, radio, informasi melalui baliho, brosur dan sebagainya (Riskesdas, 2018). Sesuai penelitian di Padang 2019 pada siswa SD, terdapat perbedaan signifikan tingkat pengetahuan dan sikap sebelum penyuluhan tentang cuci tangan dengan menggunakan audiovisual (Yanti, Alkafi, \& Bustami, 2019).

Cuci tangan yang benar menggunakan sabun dan air mengalir maupun dengan pembersih tangan tanpa air yang mengandung antiseptic dapat menurunkan jumlah koloni kuman dibandingkan dengan cuci tangan dengan tisu kering atau tanpa cuci tangan, hal ini sesuai dengan hasil pertumbuhan koloni kuman di media NAP pertumbuhan kuman yang paling sedikit dengan menggunakan hand sanitizer, tisu basah dan sabun. Kebiasaan mencuci tangan dengan sabun yang benar dapat menurunkan 50\% penderita diare di Pakistan dengan intervensi pencegahan penyakit dengan melakukan penyuluhan cuci tangan (Kemenkes, 2014). Pada tujuh merk dagang hand sanitizer terbukti sangat efektif mengurangi bakteri yang ada pada tangan. Hasil penelitian di tahun 2017, menjelaskan bahwa gel hand sanitizer dengan bahan aktif alkohol 60\% dan tisu basah antiseptik dengan bahan aktif benzalconium clorida 0,1\% efektif mengurangi jumlah koloni di tangan, tetapi tidak terdapat perbedaan efektifitas dalam menurunkan jumlah koloni kuman di tangan antara penggunaan hand sanitizer dan tisu basah antiseptic (Wahyuni, 2017). Penelitian lain di Jambi, menjelaskan mencuci tangan tujuh langkah dengan sabun cuci tangan cair triclocarban efektif dalam menjaga kebersihan tangan (Lipinwati, 2017).

Pada pengabdian ini sabun yang digunakan untuk cuci tangan mengandung bahan glycerin, potassium sorbate dan titanium dioxide. Tisu basah mengandung bahan chamomile extract $(0,1 \%)$ dan hand sanitizer mengandung polyethylene glycols-45, silica, tetrasodium EDTA dan phenoxyethanol. Bahan yang terkandung pada sabun, tisu basah dan hand sanitizer memiliki sifat sebagai bahan bakteriosidal maupun bakteriostatik. Bakteriosidal artinya kemampuan bahan kimia yang mampu membunuh bakteri, sedangkan bakteriostatik artinya kemampuan bahan kimia yang menghambat pertumbuhan bakteri. Kandungan glyceril dan polyethylene glycol bersifat sebagai bakteriosidal (mampu membunuh bakteri) untuk bakteri Streptococcus mutan, Enterococcus faecalis, E.coli (Nalawade, 2015). Sorbate bersifat bakteriostatik (menghambat pertumbuhan bakteri) untuk bakteri Staphylococcus epidermidis, Pseudomonas aeruginosa, Mocrococcus luteus dengan jalan merubah $\mathrm{pH}$ kulit dan menghambat pertumbuhan mikroba serta menurunkan pertumbuhan mikroba (Lalihta, 2015). Titanium dioxide dan silica bersifat sebagai desinfektan yang menurunkan pertumbuhan mikroba pada Streptococcus mutan (Haugen, 2016).. Chamomile extract bersifat bakteriostatik dengan jalan merusak peptidoglikan dinding sel bakteri dan bekerja saat bakteri melakukan replikasi. Chamomile dapat 
menghambat pertumbuhan bakteri Staphylococcus aureus, Staphylococcus epidermidis, Streptococcus pyogenous, Streptococcus pneumonia, Candida albicans (El-shouny, 2014). EDTA dapat merusak outer membrane sel dengan membuat lipopolisakarida menjadi hydrofobik sehingga MG2+ dan CA2+ keluar dari dinding sel (Finnegan, 2015). Phenoxyethanol memiliki sifat bakteriosidal dengan jalan leakage DNA. Dari keterangan diatas menunjukkan bahwa hand sanitizer memiliki 2 bahan kimia yang bersifat bakterosidal yaitu polyethylene glycols dan phenoxyethanol, Sabun memiliki 1 bahan kimia yang bersifat bakteriosidal yaitu glycerin dan 1 bahan bakteriostatik yaitu sorbate, sedangkan tisu basah memiliki 1 bahan kimia yang bersifat bakteristatik yaitu chamomile, sehingga memberikan efek terhadap jumlah koloni bakteri yang tumbuh di media NAP (Langsrud S, 2016). Tisu kering tidak mengandung bahan kimia yang dapat membunuh atau menghambat mikroba sehingga jari tangan yang dibersihkan dengan tisu kering jumlah bakteri yang tumbuh masih cukup banyak hampir sama dengan tangan yang tidak dicuci. Hasil pewarnaan Gram dari beberapa koloni bakteri didapatkan gambaran morfologi bentuk coccus dan batang Gram positif. Kemungkinan bakteri dengan bentuk coccus dan batang Gram positif adalah Staphylococcus sp, Streptococcus sp, Corynebacterium sp dan Proprionibacterium (Jawet, 2017).

Hasil dari pengabdian ini memberikan dampak pengetahuan individu yang akan merubah perilaku cuci tangan dengan sabun yang benar, selain itu pengetahuan yang sudah diperoleh saat ini dapat mentransfer kebiasaan cuci tangan di komunitas/lingkungan terdekatnya sehingga masyarakat dapat mencapai PHBS tentang sanitasi dan lingkungan bersih sesuai target Sustainable Development Goals (SDGs).

\section{KESIMPULAN}

Cuci tangan dengan benar perlu disampaikan pada semua kelompok usia melalui penyuluhan sebagai salah satu cara untuk meningkatkan pengetahuan bagi masyarakat karena salah satu dari PHBS. Kegiatan pengabdian ini memberikan dampak positif diharapkan dapat mengubah perilaku sehat dengan melakukan cuci tangan yang benar. Cuci tangan dengan sabun dan air mengalir, cuci tangan menggunakan pembersih tangan lain, yaitu hand sanitizer dan tisu basah dapat menurunkan jumlah bakteri yang ada di kulit tangan. Sabun, hand sanitizer, tisu basah mengandung bahan kimia yang bersifat bakteriosidal atau bakteriostatik, sedangkan tisu kering yang tidak mengandung bahan kimia tidak menurunkan jumlah koloni bakteri. Jenis bakteri yang tumbuh bentuk coccus dan batang Gram positif kemungkinan bakteri Staphylococcus, Streptococcus atau Corynebacterium. Selain penyuluhan, brosur tentang tujuh cuci tangan dapat ditempel di tempat umum atau di institusi, seperti sekolah, kantor, dan pariwisata.

\section{REFERENSI}

Benny E, W. (2010). Mikrobiologi kulit. Dalam A. Djuanda, Ilmu Penyakit Kulit dan Kelamin. Jakarta: FKUI.

Brilian, A. (2016). Gambaran tingkat pengetahunan dan sikap mencuci tangan pada ibu rumah tangga anggota posyandu di wilayah kerja UPTD Puskesmas Kecamatan Pontianak Utara. Jurnal Mahasiswa PSPD FK Universitas Tanjungpura, 3(1), 1-21. Retrieved from http://jurnal.untan.ac.id/index.php/jfk/article/view/16422

Burton, M. C. (2011). The effect of hand washing with water or soap on bacterial contamination of hands. . Int. J. Environ. Res. Public Health, 8(1), 97 - 104. https://doi.org/10.3390/ijerph8010097

El-shouny, W. A. E., El-Zaher, E. H. F. A., Khalil, M. A. E., El-Salam, O. A. E. (2014). Antimicrobial activity of Chamomile acetone extract against some Experimentally-induce Skin Infections in Mice. Egyption Journal of Environment Research, 2(2014), 58-70. Retrieved from https://www.researchgate.net/publication/280001493

Finnegan, S. P. (2015). EDTA: An Antimicrobial and Antibiofilm Agent for Use in Wound Care. Advances in Wound Care, 4(7), 415-421. Retrieved from https://www.ncbi.nlm.nih.gov/pubmed/26155384

Haugen, H. L. (2016). Antibacterial effects of Titanium dioxide in wounds. Wound Healing Biomaterial, 2(26), 1-12.

Jawet, M. A. \& Adelberg, A. (2017). Mikrobiologi kedokteran. Jakarta: EGC.

Kemenkes. (2014). Perilaku Mencuci tangan pakai sabun di Indonesia. Jakarta: Infodatin, Pusat Data dan Informasi Kementrian Kesehatan RI.

Lalihta, C. R. \& Rao, P. P. (2015). Antimicrobial efficacy of preservatives used in skin care products on skin micro biota. Journal of Science and Research, 4(6), 366-369. Retrieved from https://pdfs.semanticscholar.org/0541/5c97f35a37e8ad4eb06f579489528d05a4e1.pdf?_ga=2.14495287.106 $8177259.1588230925-1354831708.1580956150$

Langsrud, S., Steinhauer, K., Lüthje, S., Weber, K., Goroncy-Bermes, P., Holck, A. L. (2016). ethylhexyglyserin impairs membrane integrity and enhances the lethal effect of phenoxyethanol. Retrieved from https://nofima.no/en/publication/1448473/

Lipinwati, M. S. (2017). Efektivitas Mencuci Tangan dengan Sabun Cuci Tangan Cair Berbahan Aktif Triclocarban pada Mahasiswa Fakultas Kedokteran Universitas Jambi Angkatan 2015. Jambi Medical Journal, 5(1), 49 - 58. https://doi.org/10.22437/jmj.v5i1.3699 
Mustikawati, I. S. (2017). Perilaku Cuci Tangan Pakai Sabun Studi Kualitatif pada Ibu-Ibu di Kampung Nelayan Muara Angke Jakarta Utara. ARKERMAS, 2(1), 115 - 125. https://doi.org/10.22236/arkesmas.v2i1.514

Nalawade, T. B. (2015). Bactericidal Activity of Propylene glycol, Glycerine, Polyethylene glycol 400, and Polyethylene 1000 against Selected Microorganisms. Journal of international society of preventive \& community dentistry, 5(2), 114-119. https://doi.org/10.4103/2231-0762.155736

Permenkes. (2017). Peraturan Menteri Kesehatan Republik Indonesia Nomor 15 Tahun 2017 tentang Penanggulangan Cacingan. Jakarta: Menteri Kesehatan Republik Indonesia. Diambil kembali dari http://hukor.kemkes.go.id/uploads/produk_hukum/PMK_No._15_ttg_Penanggulangan_Cacingan_.pdf

Perrys, P. \&. (2015). Fundamentals of Nursing - Australian Version 5th Edition. Mosby Australia.

Radji, M. S. (2007). Uji Efektivitas Antimikroba Beberapa Merek Dagang Pembersih Tangan Antiseptik. Majalah IImu Kefarmasian 4(1), 1-6. http://dx.doi.org/10.7454/psr.v4i1.3408

Riskesdas. (2018). Laporan Nasional Riskesdas. Kementerian Kesehatan RI. Badan Penelitian dan Pengembangan Kesehatan, 321-324.

Rolf, U. H. (2014). On the Need and Speed of Regulating Triclosan and Triclocarban in the United States. Environmental Science \& Technology, 48(7), 3603 - 3611. https://doi.org/10.1021/es500495p

Wahyuni, V. K. (2017). Perbandingan Efektivitas antara Gel Hands Sanitizer dan Tisu Basah Antiseptik Terhadap Jumlah Koloni Kuman di Tangan. Jurnal Cerebellum, 3(2), 808 - 819. Retrieved from http://jurnal.untan.ac.id/index.php/jfk/article/view/23260

Yanti, M., Alkafi, \& Bustami. (2019). Perbedaan Tingkat Pengetahuan dan Sikap Terhadap Penyuluhan Cuci Tangan Pakai Sabun pada Siswa SD. Jurnal IImu Kesehatan (JIK), 3(2), 80-84. http://dx.doi.org/10.33757/jik.v3i2.219 